University for Business and Technology in Kosovo

UBT Knowledge Center

UBT International Conference

2017 UBT International Conference

Oct 28th, 3:50 PM - 5:20 PM

\title{
Ideal Model of Online Journalism, not Followed in Kosovo and Region
}

Safet Zejnullahu

University for Business and Technology, safet.zjnullahu@ubt-uni.net

Follow this and additional works at: https://knowledgecenter.ubt-uni.net/conference

Part of the Journalism Studies Commons

\section{Recommended Citation}

Zejnullahu, Safet, "Ideal Model of Online Journalism, not Followed in Kosovo and Region" (2017). UBT International Conference. 205.

https://knowledgecenter.ubt-uni.net/conference/2017/all-events/205

This Event is brought to you for free and open access by the Publication and Journals at UBT Knowledge Center. It has been accepted for inclusion in UBT International Conference by an authorized administrator of UBT Knowledge Center. For more information, please contact knowledge.center@ubt-uni.net. 


\title{
Ideal model of online Journalism, not followed in Kosovo and region
}

\author{
Safet Zejnullahu1 \\ UBT-Higher Education Institution, Lagjja Kalabria, 10000 p.n., \\ Prishtinë, Kosovo \\ safet.zejnullahu@ubt-uni.net
}

\begin{abstract}
In the process of seeking to fulfill the audience needs from online journalism, the World's most important medias have managed to perform and finalize the experiment "eye-follower". As a result, reader's areas of interest while they are browsing the internet while using information technology equipment are obtained. Therefore, CCN, BBC and The Guardian used the data from this experiment to design their online portals, and in the way how they are going to write articles, together with the illustration of other elements. Moreover, this paper covers the research of using the approach of this experiment also in online portals in our country and in the region. Subject of analysis are five portals from Republic of Kosovo: "koha.net"; "gazetaexpress.com"; "indeksonline.net"; "telegrafi.com" and "zeri.info"; two from Albania: "shekulli.com" and "topchannel.tv"; two from Macedonia: "zhurnal.mk" and "lajmpress"; one from Croatia: "jutarnji.hr", one from Serbia: "b92.net"; one from Bosnia and Hercegovina: "dnevni avaz"; and one from Montenegro: "vijesti.me". Analysis of the similarities (a few) and differences of the "other" elements, which were chosen by these media to gain the interest of the online journalism readers.
\end{abstract}

Keywords: journalism, internet, “eye-tracker”, design

\section{Introduction}

The main concern with the internet is that it removes concentration/focus from the people. It is even scientifically proved that the golden fish has more focus and concertation in comparison to the human. Internet's average reader is only focused for eight seconds, while golden fish is focused for nine seconds. Hence, there are several writing rules which should be followed to be able to keep the reader's attention as much as possible, therefore making them read our text. These rules are followed by main international medias including $\mathrm{CNN}, \mathrm{BBC}$, Guardian and many others but also humans while writing marketing news.

\section{Fundamental writing rules for web}


Rules for writing in web were established by researching the way how people read the digital media. This was shown by a device called "eye-follower", which was placed in the people heads and could show in which part of the screen the reader is looking.

Research results were used to set the rules for writing in the web platform:

People do not read your texts, instead they scan them.

What does "scanning" mean? It means that people open your text, look at the title, read the beginning of the text, then move to the second paragraph, then move down to the first subtitle, look left and right and then get back to the beginning.

Simply said, one "stihik" read, eyes look up in every direction and almost no one reads the entire text carefully, line by line. In only rare cases the person reads the text completely. Below is an explanation of the process during a session with "eye-follower". It is scary. After a hard work and a lot of energy consumption to plan each word and sentence in our text and people open it and stay indifferent toward our text. No need to complain, instead let's use these results to be able to write texts according to the reader's requests. What do people think? The fact that a user might click the text doesn't mean that they are going to read it. Initially, their intention is to check on whether it is worth to read that text, how much time they need for it and if the text is interesting enough for them. How is this achieved? In the first step "they fly through the entire text". During this "fly" through the text they can decide if they are going to start reading it, this means that in case they are dealing with a text which doesn't followed these rules, they will move away without reading it. Hence, please do not philosophize and do not use the following.

Follow the advices below:

First, the text width should be around 80 characters. Depending on the web page, it can fall within the scope $70-90$ characters. Moreover, the left and right margins from the text should be of the space that two big letters have. Again, depending on the webpage the space might be larger but not smaller. If the text is limited with strict lines in the sideways then the people might be in tension since it feels like holding them blocked into an elevator or similarly. The length of the paragraph is very important. Tend to write paragraphs of 3-4 lines long, and in cases you need to include more dynamic into the text than you can extend the paragraph to a maximum of 6-7 lines.

At first glance, all these might influence the reader's mind by creating the impression that the text is interesting. During the initial text scan that reader performs, you can take his attention by using bold in the key words. Please do not over use it. One text which contains a lot bolded words or parts creates the impression that it is either very important or not important at all. Be careful with the outdated ideas like "Subtitle explains the topic which is being cover in the text" for the subtitles or middle titles. In the internet texts, middle title is used as a feature to keep the level of attention.

You can use a middle title in the text as soon as you think that it is needed. If several paragraphs have been written and there is not any good explanation photo, then it is the time to add a middle title. Please bear in mind that the potential user may have simultaneously several tabs opened and in the meantime, they receive continuous notifications from social medias. Let's create a text content which keeps the readers linked with your text and tab until they you're your text completely.

Another frequent mistake noticed is regarding the font size which is used in the published text. There is no predefined rule about the font size, however you can be the best measurement instrument. After browsing through various webpages and seeing various font sizes then determine what is best for your eye, and use the same for your text. If there are still doubts, then it is good to consult with professionals in the design area, and they should be able to support you in this direction. A more important element rather than the selected font, is the fact that title, subtitle and middle title should have a special font, for example, a larger font should be used to attract the users' attention.

Always use the principle of the inverted pyramid (but this is not like in the classic journalism). 
The invented pyramid is the most important element of writing for web, which does not stand for the classic journalism. In the classic journalism, we have learned that the inverted pyramid is interconnected with the content of the entire text. So, at the beginning of the text are provided the main elements while the other part of the text consists of less and less important elements, descriptions and fact with less interest and value. Almost similar behavior exists also in the digital media but a slightly different. This model deals with every paragraph within the text and not only, it deals with each sentence, and not with the text as an entirety. Why?

Let's get back to the experiment mentioned above "eye-follower". Tests have shown that the reader while scanning the text, he/she reads only the beginning of each paragraph. Therefore, this scanning is the determination factor on whether he/she is going to read the text or not. Similarly, also the middle titles, photos and other highlighted factors within the text are scanned. If the important facts and keywords are not part of the beginning of the paragraph and/or middle titles then the reader won't see it while scanning and may ignore the text. Therefore, the attention of the reader will raise proportionally with the important elements and keywords being added into the above-mentioned places. Always, always, always use the inverted pyramid method in your Facebook posts.

\section{How much is the rule followed by online medias in Kosovo and region?}

To determine if this experiment is followed in practice we have analyzed numerous news portals in Kosovo and region. Subject to the analysis are 5 portals in Kosovo, 2 in Albania, 2 in Macedonia, one in Croatia, one in Bosnia, one in Montenegro, and one in Serbia.

For analysis purpose, the text "Bizneset thonë se në Kosovë "nuk ka papunësi” por ka "papunëtorë" has been taken from "koha.net" portal in 28th of July 2017. The text width in this portal is always smaller than preferred based on the experiment explained above. Most of the sentences contain 5565 characters.

Example:

Në Kosovë pothuajse për çdo vit, kompanitë private, konkretisht $=63$

ato në sektorin e bujqësisë, ndërtimtarisë dhe lokalet shërbyese, $=65$

përballen me problemin e punësimit sezonal të punëtorëve. $=57$

Regarding margins, this portal is special, because the size of the left margin is similar with the one of this experiment, so about two capital letters, while the right margin is very big, almost 20 small letters. Whenever the news is a bit longer than usual, the portal usually places a subtitle which does not differ from the other part of the text regarding the font size, instead it is highlighted in bold. Moreover, subtitle does not tend to be "a short summary of the text", but only "the beginning of the text marked in bold".

The paragraph width it is generally acceptable. The text subject of analysis contains 21 paragraphs where the smallest one has 2 rows and the largest longest one has 7 rows. A photo from the archive is included in the beginning of the text, while there isn't any other photo included in the rest of the text. Even though the nature of the text is to be a long text for an online media, it does not contain any middle-title. Despite the first paragraph, in the text you cannot find any other word or sentence highlighted in bold, while the font is of standard size. In the other hand, the portal does not other the technical capability to increase the font size, which would ease the reading for persons who have 
trouble in reading. In the classic journalism, we have learned that the inverted pyramid is interconnected with the content of the entire text. This rule applies also for the online media. However, it is not sufficient to attract and keep the reader for a full text read. Despite the fact of using the inverted pyramid, also each paragraph should include sufficient elements to seem like a mini-pyramid. Moreover, it is very important that every paragraph to start with important things.

Let's analyze how this works in the text which is subject of our analysis:

From the technical point of view, text lacks middle titles and illustrations within, therefore it may be unattractive for the reader. While from the professional side, text contains sufficient sources and the writes has chosen several solid words to start the new paragraphs, and sometimes even has started the paragraphs with citations, which in general are attractive to read.

While in the portal "gazetaexpress.com"we face a different state. The row width generally falls within the scope of our research values, so the width is approximately 80 characters, but does not fall below 70 and does not go above 90 characters.

Example:

Ministrja në detyrë e Integrimeve në një intervistë për Ekonomia Online thotë se nuk $=84$

ka parametra vlerësues ose matës se deri në cilin stad është luftuar korrupsioni. $=81$

Madje ajo thotë se asnjëherë nuk mund të thuhet se korrupsioni është luftuar $=76$

This portal uses standard margins in both sides of the text, therefore it does not create gaps in the text. First three rows of the text are written in capital, but they are not classic middle titles, instead it is just a regular text beginning. Moreover, text does not have middle titles. In order to illustrate, a photo of the text personage is provided in the beginning, while there are no other illustrations within the text. Likewise, there are no bold or italic marked word nor sentences within the text. Text contains 15 paragraphs, which in general are longer than the preferred average by this experiment. Regarding the content, the satisfactory level of correlation between title and content is very low. In fact, the title might include "demarcation", while the beginning of the text does not deal with this topic at all - it focuses in the "corruption" fighting, as one of the crucial elements to get visa liberalization. In general, if this portal offered an acceptable technical solution, then the order of the crucial elements in the beginning of the paragraphs is not such attractive, therefore it cannot be considered as a good solution which would serve as a bait for the reader.

The other portal subject of analysis, "indeksonline.net", in most of the cases uses standard rows which fall within the parameters of our research, around 80 characters within a row.

Example:

Dy emrat më të përfolur për të kandiduar për Kryetar të Kuvendit, Kadri Veseli e $=80$

Xhavit Haliti, nuk janë emrat e vetëm që mund të përfaqësojnë Kuvendin me së = 76

miri.

However, the right margin is placed based on the standards, while the left margin contains a huge blank space, which when joined with the other part of the screen out of the design of the portal creates a big blank space.

Text does not contain subtitle nor font highlighting in the first rows, it does not contain middle titles while it includes only one illustration photography in the page header.

Text contains 21 paragraphs, where the longest paragraph has 7 rows and the shortest one has 1 row. Text includes various cited sources, while the issues placed at the beginning of each paragraph are various and attractive. 
The other portal, "telegrafi.com", utilizes the lowest border of preferred character per row, usually there are less than 70 characters per row.

Example:

Ahmeti tashmë si kryetar i Prishtinës, Arban Abrashi ish-ministër i Punës $=74$

dhe Mirëqenies Sociale, Lirak Çelaj ka qenë zëvendësministër në $=63$

Ministrinë e Drejtësisë, kurse Arbër Vllahiu ishte këshilltar $i$ ish- $=68$

Text does not include a standard subtitle, but likewise in most of the portals, the initial paragraph is written in capital letters and marked with bold.

There is only on photo in the beginning, while throughout the text, instead of other illustrations there are two advertisements, one after the first paragraph and the other after the seventh paragraph. There are no middle titles nor words or sentences marked in bold.

Text has 16 paragraphs, where the longest one contains 4 rows and the shortest one contains 1 row. Referring to the mini-pyramid principle, the text contains attractive paragraphs and initial words which are attractive in the beginning of the paragraph.

However, based on the principle that the reader usually scans the text with one quick view to determine if he/she is going to read the text or not, therefore the advertisements which create a significant space between paragraphs seem to be discouraging for the reader.

Portal "zeri.info", utilizes even shorter rows. Generally, they include 60-65 characters per row, which obviously is much less than the preferred model based on the research that is being performed.

Example:

Njohës të rrethanave politike në vend kanë vlerësuar se bllokada $=64$

institucionale në vend mund të zgjasë deri pas përfundimit të $=61$

zgjedhjeve lokale në vend, e të cilat do të mbahen më 22 tetor të $=65$

këtij viti, shkruan sot, gazeta Zëri.

In addition to the other portals "zeri.info" uses a classic subtitle marked in bold which tends to form a summary of the main topics in the text.

Moreover, the text contains three middle titles which make it much more attractive. There is only on standard illustrations in the beginning of the text while the rest of the text does not contain any photo.

Margins in this portal are a bit more specific. While in the first five paragraphs the margins are standard and there is no feeling of gaps or bottlenecks, after the fifth paragraph it seems like a boat in the ocean, where margins in both sides of the text are larger than the text itself. Another issue which might prevent the reader from focusing in the text is that in the first part there are also publications sideways which contain one title and a bit photo and take the reader's attention more than the main text itself. Text contains 28 paragraphs, the longest one is 6 rows but the majority are 4-5 rows long, which falls within the best practices.

There are two advertisements within the text, one in the beginning and the other after the third paragraph which create a small discontinuity of the text and might affect enough the readers decision on whether to read the text of not. Here, the text can be considered as generally complaint with the mini-pyramid principle, which is achieved by the usage of middle titles and attractive citations which are selected to start the paragraphs with.

In the Tirana's portal "shekulli.com" the standard rows are all above the ideal model of 80 characters, and generally they tend to exceed the higher preferred limit of 90 characters. 
Example:

Instituti i Studimeve Politike përmes projektit monitorues 2017-2020 www.deputetim.al, $=87$ mbështetur nga qeveria e mbretërisë holandeze ka ofruar të dhëna publike që lidhen me $=85$ përbërjen e parlamentit, cilësitë e përfaqësimit, prurjet, risitë dhe problematikat. Të dhënat =94

But a characteristic of this portal is the complete different structure in comparison with other portals in Albania and region. There is an initial illustration without a classic subtitle but there is a bow which as a model is quite good to attract the people to read the text.

However, all elements of the text are a bit different. Text is separated in two blocks, with one short middle titles and does not contain any classic paragraphs. One block contains 20 rows while the second one 23 rows. With a fast view, the chances are higher that you wouldn't decide to read it. Margins are standard.

While the other Tirana Portal subject of analysis, "top-channel.tv" has a different page structure with rows that rarely utilize more than 60 characters but in most of the cases are 10 characters smaller.

Example:

Ardhja për të jetuar në Shqipëri e pensionistëve nga vendet e $=61$

Bashkimit Evropian mund të jetë një mundësi e mirë për $=54$

ekonominë e vendit për të rritur të hyrat në valutë. $=52$

Text does not contain highlighted subtitles or middle titles, nor any sentence highlighted in bold. There is a standard illustration in the text header. There are seven paragraphs which include from 2 to 6 rows. There is a good selection for the words which are used as paragraph starters, and there are no advertisements to discourage the reader to start reading. Instead, the margins (photos) are not well placed. There is too much empty space in both sides, which is quite discouraging and as per the research basis it is an unattractive element for the reader.

Completely out of the standards considered for this research is the portal from Skopje "zhurnal.mk". This portal is one of the most read portal in Albanian language in Macedonia and utilizes row structure which is above 90 characters and has the tendency to generally use long rows.

Example:

"Dështimi i këtyre partive ka qenë që në start. Për shkak të miopisë së tyre politike dhe lakmisë =98 për pushtet, pranuan të hyjnë në qeveri pa ato kërkesa që dilnin nga Deklarata e përbashkët e =93 partive politike shqiptare, e njohur si "Platforma e Tiranës". =62

Text has eight paragraphs, two of them have 9 rows, and the shortest one has 2 rows. There is no subtitle nor highlight in the beginning of the text, likewise there are no middle titles. Illustration and the text in the beginning are separated by an advertisement. Right margin falls within the standards, even though it may lose the focus of the view in the text, because the right margin is full of photos. While in the left side, the margin includes a very wide area, almost as half of the text. The beginning of the paragraphs is not enough attractive to initiate a read, where you have the idea (in two-three cases) that the paragraphs are created only that they include less rows.

However, this portal is closer to meet the ideal model compared to the other Albanian portal in Macedonia "lajmpress", where the standard rows contain 140 characters, which means double of the ideal row size. 
Example:

Partitë kanë hyrë në fazën e fundit të përzgjedhjes së kandidatëve me të cilët do të garojnë në zgjedhjet lokale të 15 tetorit. Në disa komuna $=142$

tanimë kandidatët e disa partive janë thuajse të sigurt, ndërsa në shumë komuna partitë kanë ende problem në përzgjedhjen e kandidatëve. Edhe $=141$

në këto zgjedhje situata më e tensionuar duket në BDI. Nga kjo parti deri më tani kanë zgjedhur vetëm kandidatin për Komunën e Kërçovës ku në =139

Text is illustrated with logos of six political parties, with no subtitle nor middle titles. However, the text contains three paragraphs, one would be 9 rows long, the second one 4 rows and the last on 8 rows long.

The initial paragraph words are not well selected to capture the readers' attention. Margins fall within the standard model subject for this analysis. Similar with the state of the portals in Albanian language, is also the state of portals also in the region. Croatian portal "jutarnji.hr" has a row structure within the borders of our ideal model, with standard rows of 80 characters.

Example:

Uragani Harvey kaloi në tokë në brigjet e Teksasit dhe përfshiu qytetet Corpus $=73$

Christi e Rockport, ku dëmet ende po vlerësohen, dhe po shkon shumë më ngadalë, për ç'shkak =86 ekziston rreziku real se do të pasohet nga vërshimet katastrofave $=79$

Text does not include any subtitles nor middle-title, but in some of the paragraphs there are some words marked in bold, which are used as key points to understand the topic. One special characteristic of this portal is that after two-three paragraphs there is a photo or short video which makes the read much more attractive.

In total, text has 10 paragraphs, where each of them has 4-6 rows. The paragraphs start with information and facts that are attractive and generally fulfill the criteria of the text written in some mini-pyramids. Regarding margins, they are out of standard and therefore offer the idea of a gap. Similar state is also noticed in the Serbian portal "b92.net", where the row width is also around 80 characters.

Example:

A e ka humbur Sorosi fuqinë e tij të punës ose po sheh diçka që të tjerët nuk e shohin? Dhe çka =85 për gjendjen globale ekonomike, të sistemit neoliberal ekonomik në të cilin jetojmë, $=74$

flet fakti se dhjetë individët më të pasur në vitin e kaluar...=76

Text written in 17 paragraphs, where the longest one contains 8 rows and most of them fall within the required standard. Moreover, most of the paragraphs fulfill also the minipyramid criteria. While, text does not contain subtitles nor highlighted sentences at the beginning, neither middle titles and nouns highlighted in bold within the text. The right margin is within the criteria, while the left margin contains a huge blank space, almost like half of the text. Portals from Bosnia and Hercegovina, "dnevni avaz" has a row structure which falls outside the model subject of analysis. Here, standard rows contain 100 or more characters.

Example:

Babai i tij një ditë u martua. Solli një grua të re dhe të bukur. Aliu e respektoi njerkën si=98 
Nënëne tij. Por, njerka u dashurua në thjeshtrin. Çdo ditë, gjithnjë e më shumë i bënte presion $=112$

atij, duke dashur qëta bëjë përvete. Aliu u tërhoq anash, ikte, heshtte... një ditë, duke mos mundur të durojë më, $i=106$

But the text length does not remove the text attractivity, because several photos are spread across the text, like the middle titles and sentences highlighted in bold which are sufficient in order to obtain the reader.

Text contains 17 paragraphs, where each of them includes 5-6 rows and the minipyramid criteria mainly has been followed. In general margins fall within the standard and offer the possibility to focus in the text. Portal from Montenegro "vijesti.me" includes rows with standard structure, with tendency of having rows with 75 characters.

Example:

Rrëfimi aktual për rishkruesit e reformës shkollore, ose - rrëfimi i ri për $=78$

intelektualët mashtrues malazezë të secili lloj-është shumë $=65$

interesant në atë lloj në të cilin tregohet mekanizmi i funksionimit... $=75$

Text is composed of 11 paragraphs, most of them are long, while two of them contain 11 rows. Even though the paragraphs are long, they create a structure and contain attractive words at their beginnings. Meanwhile, there is no sub or middle title, nor like there isn't any bold highlighted word. Margins are within standards.

\section{Conclusion}

Will the reader stay or move somewhere else? Are there enough distinctive elements which could affect the readers to decide in their first sight if the text is worth reading or not?

Generally, none of the portals under investigation does not fulfill all the requirements based on the research taken as a sample. Regarding the row width, it is clearly noticed that only half of the portals use standard rows while the others generally have longer rows which are weary for reader's eyes, while some portals used shorter rows.

An improved state seems to be at the paragraph width, where it is shown an increased awareness building in terms of writing short paragraph, even though there are two cases when this is not considered at all.

Only less than half of the texts fulfill the important criteria of writing in the form of mini-pyramid. In most of the cases, you have the impression that the new paragraph has been started just to fulfill the criteria of short paragraph, rather than finding one important element to start the new paragraph with an attractive topic or issue.

Almost in all the portals you have the impression that they are facing dilemma between traditional text in hardcopy media and text in news portal while choosing the proper text structure. Generally, they hold an improvised subtitle (marked in bold but without a subtitle content) and rarely middle titles. Most of the portals use only one picture in the text header and consider this to be enough. Even though a longer text with numerous pictures would make it much more attractive.

While the margins topic is not handled in priority by the none of the portals even though a technical solution in this case would increase and maintain the amount of readers. Two interesting behaviors 
are noticed in this direction, either there is a huge blank space or a space filled with pictures in the margins section. Nevertheless, it seems to be more attractive and relevant to the reader when they do not see a huge blank space but instead they see some pictures.

Adding the fact that advertisement is noticed to be in the beginning of the text and after two-three paragraphs then it can be stated that the news portals in Kosovo and region did not focus on finding professional elements to attract the readers. They were constantly searching for new elements which would possibly attract the reader. Fake titles, which are not filled with content, fake photos, attractive facts but unverified, trivial personages, cheating by hiding the name where the important event has happened and similar elements should be crucial points for the portals to try and compete with quality news and proper design selection. These two elements improve the media by making it more attractive not only in the online journalism but in all types.

\section{References}

1. http://amtec.us.com/blog/are-you-applying-for-the-wrong-jobs

2. http://www.koha.net/arberi/33341/bizneset-thone-se-ne-kosove-nuk-ka-papunesi-por-kapapunetore/

3. http://www.gazetaexpress.com/lajme/ahmetaj-therret-per-ratifikim-sa-me-te-shpejte-temarreveshjes-per-demarkacion-411820/

4. http://indeksonline.net/lajmet/flora-brovina-e-pranueshme-per-kryetare-te-kuvendit-pervv-dhe-laa-113418/

5. http://telegrafi.com/kjo-eshte-pasuria-e-kandidateve-per-kryetar-te-prishtines/

6. http://zeri.info/aktuale/158955/bllokade-deri-pas-zgjedhjeve-lokale/

7. http://www.shekulli.com.al/ja-sa-biznesmene-deputete-ka-ne-parlamentin-e-ri/

8. http://top-channel.tv/lajme/artikull.php?id=362226\&ref=ml

9. http://zhurnal.mk/content/?id=178252225538

10. http://lajmpress.com/partive-politike-u-kane-mbetur-edhe-15-dite-per-te-perzgjedhurkandidatet-video

11. http://www.jutarnji.hr/vijesti/svijet/najmocniji-uragan-u-12-godina-pogodio-amerikustete-se-vec-zbrajaju-a-ocekuju-se-katastrofalne-poplave-zbog-kojih-su-tisuce-vecevakuirane/6492454/

12. https://www.b92.net/biz/vesti/svet.php?yyyy=2017\&mm=08\&dd=26\&nav_id=1297054

13. http://www.aura.ba/prica-o-turbetu-hazreti-alije-iznad-trnave-kod-sanskog-mosta-kad-jemajka-maceha-otac-je-ocuh/

14. http://www.vijesti.me/forum/prevaranti-951770 